$\begin{array}{ll}\text { Research Square } & \begin{array}{l}\text { Preprints are preliminary reports that have not undergone peer review. } \\ \text { They should not be considered conclusive, used to inform clinical practice, } \\ \text { or referenced by the media as validated information. }\end{array}\end{array}$

\title{
Geochemical Characterization of Geothermal Spring Waters Occurring in South Part of Gujarat and West Coast Geothermal Province of Maharashtra, India
}

Anirbid Sircar ( $\square$ anirbid.sircar@spt.pdpu.ac.in )

Pandit Deendayal Petroleum University School of Petroleum Technology

Kriti Yadav

Pandit Deendayal Petroleum University

Namrata Bist

Pandit Deendayal Petroleum University

Hemangi Gaurangbhai Oza

Pandit Deendayal Petroleum University

\section{Research Article}

Keywords: Geothermal water, Physiochemical characterization, Tural-Rajwadi hot springs, Saputara geothermal spring, Unai, West Coast Geothermal Province.

Posted Date: June 15th, 2021

DOI: https://doi.org/10.21203/rs.3.rs-542459/v1

License: (9) (i) This work is licensed under a Creative Commons Attribution 4.0 International License. Read Full License 


\section{Abstract}

Geothermal waters are extensively useful for various purposes such as in industrial plants, societal benefits, irrigation, and domestic consumptions. However, its physiochemical characterization is very important before using it for any rationale. The main objective of this paper is to identify the hydrochemistry of geothermal water which is placed in southern part of Gujarat such as Unai hot springs and Saputara geothermal springs, and west coast geothermal province (WCGP) like Tural-Rajwadi group of hot springs. The standard methods were used to carry out the analysis of geothermal water. Piper, Stiff, Gibbs, Extended Durov, and Wilcox diagrams have been plotted to categorize water samples in facies. Spatial distribution curves have also been plotted for geothermal regions of Gujarat and Maharashtra. The geochemistry of groundwater is influenced by the presence of most important ions like $\mathrm{Na}^{+}, \mathrm{Ca}^{2+}, \mathrm{Mg}^{2+}, \mathrm{K}^{+}, \mathrm{Cl}^{-}, \mathrm{HCO}_{3}{ }^{-}$, and $\mathrm{SO}_{4}{ }^{2-}$. Geothermal spring of Unai contains high TDS concentration around $1000 \mathrm{mg} / \mathrm{l}$ thus it cannot be used for drinking purposes but it can be utilized for domestic, balneology, and industrial purposes. However, after desalination this water can be utilized for drinking purposes. In Tural-Rajwadi hot springs TDS concentration was $>900 \mathrm{mg} / \mathrm{l}$ and $\mathrm{pH}$ range was between7-8 hence it can be used for domestic and industrial purposes. The temperature range of Tural-Rajwadi geothermal hot spring is $55-65^{\circ} \mathrm{C}$ which is very useful for milk pasteurization, industrial operations, space heating, balneology facilities like greenhouses and aquaculture ponds, and domestic purposes.

\section{Introduction}

As geothermal energy is very clean and having a low maintenance cost it is being utilized as another energy source across the world. The earth's interior contained geothermal energy and it apparent in several forms, varied from a higher geothermal gradient to hot springs, fumaroles and volcanoes (Monterio et al. 2019). Geothermal water is very essential natural resource which can be used for various purposes such as domestic consumptions, industrial operations, irrigation, and therapeutic facilities (Yadav et al. 2021). In India many geothermal fields have been recognized, among them few are having a high potential and some are having a medium to low potential. Around 300 hot springs have been observed across India, which occurred due to the presence of diverse tectonic elements like shear zones and fault planes. In 1991 many geothermal Regions identified by GSI they are Himalayan Geothermal Region, Andaman-Nicobar Island Region, West Coast Region, Cambay Graben Region, Son-Narmada-Tapi Region, Aravalli Region, Godavari and Mahanadi Region, and South Indian Cratonic Region (Monterio et al. 2019). Geothermal provinces of India are as shown in Fig. 1.

Among all these geothermal regions, Cambay Graben Region (latitudes $21^{\circ} 00^{\prime}$ and $25^{\circ} 00^{\prime} \mathrm{N}$ and longitudes $71^{\circ} 30^{\prime}$ and $73^{\circ} 30^{\prime} \mathrm{E}$ ) in Southern part of Gujarat and West Coast Geothermal Province (WCGP) ( $19^{\circ} 42^{\prime} 43^{\prime \prime} \mathrm{N}-72^{\circ} 50^{\prime} 55^{\prime \prime} \mathrm{E}$ to $\left.16^{\circ} 38^{\prime} 44^{\prime \prime} \mathrm{N}-73^{\circ} 31^{\prime} 52^{\prime \prime} \mathrm{E}\right)$ of Maharashtra are the most potential geothermal fields (Low et al. 2020). The hot springs at Unai is located in southern part of Gujarat. In the southern part of Gujarat, the geological developments vary from Cretaceous to Holocene (Shah et al. 2019b). The pH values of 7.5-8.5 were detected in water samples from the hot springs of Unai that reveals the alkaline nature of water. Amusingly, these hot springs were having temperature values between 51 to $56^{\circ} \mathrm{C}$ hence it can be used for industrial operations, societal benefits, and domestic consumptions. The TDS concentration of 900-1000 mg/l was observed in hot springs of Unai (Yadav et al. 2021). Saputara (20囚34'47" N-73ه44'48" E) is placed in Western Ghats and it is a part of Dang district in Gujarat. Detailed geochemical analysis of thermal springs of Saputara has been carried out in this study. Physico-chemical parameters of thermal spring water of Saputara region is similar to thermal spring water of Unai.

In West Coast Geothermal Province (WCGP) above sixty thermal springs are available at eighteen locations, containing temperatures between 40 to $72^{\circ} \mathrm{C}$. These thermal springs are passing through the Palghar, Raigad, and Ratnagiri district of Maharashtra and they are covering up the linear distance of around $350 \mathrm{~km}$. Even though these thermal springs are issuing through the $65 \mathrm{Ma}$ Deccan Volcanic Province (DVP), the major ion chemistry point out the impact of underlying formations that superimpose the Precambrian granite-gneiss (Chandrasekhar et al. 2018). These thermal waters are having lower concentration of $\mathrm{Mg}^{+}, \mathrm{K}^{+}$, and $\mathrm{HCO}_{3}{ }^{-}$and having enhanced concentration of $\mathrm{Ca}^{2+}, \mathrm{Na}^{+}$, and $\mathrm{Cl}^{-}$. In this region Tural-Rajwadi cluster of hot springs has gained more attention due to high temperature potential $\left(50-61.5^{\circ} \mathrm{C}\right)$ and medium TDS concentration (>900 mg/l). The discharge rate of Tural-Rajwadi group of hot springs was observed around 5 Ips and it was dispersed over an area of $\sim 1.5 \mathrm{~km}^{2}$ (Low et al. 2020). This group of hot springs is regulated by dykes, shear zones, fractures, and the NNW-SSE trending lineaments. Tural-Rajwadi hot spring water can be utilized for societal benefits, industrial applications, and domestic consumptions.

In developing areas of Maharashtra and south Gujarat very few facilities of electricity, irrigation water, and domestic water are accessible to the people due to lack of physicochemical analysis of the thermal spring waters located in this regions. In order to overcome this problem the main objective of this study is to perform the hydro-geochemical analysis of these thermal spring waters as highlighted by circle in Fig. 1 After performing this study use of this thermal spring water can be enhanced. Various plots such as Gibbs, Pipper, Stiff, and Durov have been plotted in this study. During the hydro-geochemical analyses of water, the physicochemical and geological assessments were of enormous importance because they disclosed the relationship between chemical factors, water type, and geology of the area (Jahangiry Fard et al. 2019). The geochemical studies reveal the origin of geothermal water. The chemistry of the geothermal fluids is largely dependent on the reservoir temperature, type of reservoir rock, mixing processes, multiple fluid origin, altitude of the infiltration basin, and underground travel time (Shah et al. 2021). A range of impurities dissolve in it while water is transport. Many fine particles flow with water through many procedures such as weathering, microbe decay, soil leaching etc. (Rahimi et al. 2019).

\section{Geological Setting}

\subsection{Southern Part of Gujarat}


In Gujarat, 22 thermal regions are present containing 17 thermal springs that extend from Archean to Quaternary in attribution within the Cambay Basin as its main tectonic structure. Unai is the most important geothermal field that is placed in southern part of Gujarat (Sircar et al. 2015). It is 100 km away from the Cambay Basin. The surrounding areas are having the elevation of 10 to $55 \mathrm{~m}$. This area is mostly covered by dense forest and small hillocks. This region is largely shielded by the thick Deccan trap of Late Cretaceous to Early Eocene age (Biswas 1987). The whole area of Saputara is also a part of Deccan Trap. This region shows rugged and terraced topography with plane peaked conical hills, small plateau and steep side narrow valleys. Basaltic lava flows are surrounded by black clayey to loamy soil. Its width is around a meter (Gupta, 2014).

South Gujarat has developed with the fragment of the Gondwanaland. Throughout early Cretaceous sedimentation and volcanism have initiated with the marine transgression beside that the Narmada geofracture offered grow to the equivalents of Bagh beds (Yadav and Sircar 2019). Succeeding procedures contained Deccan volcanism and evolution of the cambay basin. Quaternary deposits contained alluvial accumulations and coastal marine deposits (Sircar 2017). The Narmada-Son Lineament comprised of Unai hot spring and it separates the Indian shield into two parts (Shah et al. 2019c). The Deccan lava flows is one part that is prevailed in the western part of Narmada-Son Lineament. These basaltic lava flows of the Deccan Trap compose the main rock formation of the southern part of Gujarat (Sircar et al. 2015). These trappous rocks contain horizontal lava flows. This trap appears flat-topped hills because of deviation in the hardness of the dissimilar flows. These traps achieve their highest altitude close to the border of Gujarat and Maharashtra, i.e. Dang area (Rao et al. 2012).Various dark grey basalts are available in Lava-flows, quite frequently amygdaloidal and porphyritic. In the subsurface there is also a possibility of presence of hard rock. In Saputara (Dang district Gujarat) different elements of basaltic lava flows form the main aquifer system. In pheratic condition ground water occurs. In this terrain weathered and fractured volcanic rocks are present in unconfined aquifer. There is a high variation in the areal extent and thickness of weathered mantle. The southern part of the region is criss-crossed by dykes that regulate the transfer of groundwater in the development.

\subsection{West Coast Geothermal Province (WCGP)}

The Deccan Volcanic Province (DVP) of West Central India is pointed by three main tectonic zones they are Narmada-Son rift, the West Coast zone, and the Cambay rift. These regions are tectonically disordered spots of fracture zones, dyke swarms, and hot springs. The DVP comprising of lava flows of various thickness ( 40-100 m) and it imbricate the pre-Cambrian basement of the Indian subcontinent (Shah et al. 2019b). Inception of DVP is ascribed varyingly to the magma eruption structured by the melting of a mantle plume, lithospheric plate tectonic processes, and effect of huge extraterrestrial bodies. The hot springs located in West Coast Geothermal Province of Maharashtra, India visible in hard rock of Deccan basalt land with meager alluvial shield. It is considered that the real hot waters are released from the margins of dykes, intense fractures, and shears (Rao et al. 2015).

In the Tural-Rajwadi group of hot springs region there are five lava flows on the surface and six lava flows in a bore well at Rajwadi (Monterio et al. 2019). These six lava flows have been recognized based on their internal structure, textural variations, vesiculation and presence of glassy rinds. Vesicle and joint fillings within the lava flows expose peculiar assemblage of calcite, nontronite, clinopitolite, stilbite, apophylite, cristobalite, etc. it indic this signifying mineralization correlated to flowing hot geothermal fluids (Pujari, 2014). A main portion of the Tural-Rajwadi region is engrossed by valleys with hilly region and a wide plateau in the north-east, eastern, and south-eastern parts. There are two major streams drain the area. In a north-south direction, the Turalnala flows and Rajwadi stream transfer from east to west. The Rajwadi stream is described by short rectilinear stream fragments. Bedrock contains the basaltic lava flows and most of the steams cut through this bedrock.

\section{Sampling And Analytical Techniques 3.1 Sampling Method}

Thermal spring water and ground water samples were collected from various locations in Southern Part of Gujarat and West Coast Geothermal Province (WCGP) for lab analysis. Giggenbach and Goguel, 1989 had mentioned sampling method which was adopted for the sampling during this study. After pumping of $20 \mathrm{~min}$ samples were collected from the wells in order to avoid non representative sample and polluted water. Two bottles of 1-I samples were collected from each sampling site. Out of two bottles in one bottle filtered sample (with acetate cellulose filter paper having pore size of $0.45 \mu \mathrm{m}$ ) was filled. The sample bottle was rinsed three times with filtered water before the filtered sample was collected. After that this filtered water samples were acidified with $\mathrm{HNO}_{3}$ (Merck 65\% purity). The second bottle which is filled with the unfiltered water sample was initially acidified and then filtered in lab. These bottles were then sealed with parafilm and transferred to our lab for further analysis. In order to determine anion concentrations $\left(\mathrm{HCO}_{3}{ }^{-}, \mathrm{Cl}^{-}, \mathrm{SO}_{4}{ }^{2-}\right.$, $\mathrm{F}^{-}$) unfiltered and unacidified samples were also collected in 1-I of HDPE bottles.

\subsection{Analytical Techniques}

Physical parameters like electrical conductivity (EC), temperature, and pH were determined in the site immediately after sampling by using Orion 4-Star meter. The major ion concentrations like Chloride, Calcium, Magnesium, Sulphate, Fluorides, Bicarbonates, and Carbonates were determined by standard APHA methods (Rhodes 1980). Sodium and potassium were analyzed by means of Flame photometric and EDTA methods (Armijo 2012). Total Dissolved Solids (TDS) was determined by gravimetric method. The sources of dissolved components in water can be understood by piper graphic method. The fundamental principal of this method is that in water cations and anions are usually in chemical equilibrium. The sodium percentage (\%Na) and electrical conductivity (EC) of the water were identified by Wilcox and Wilcox Log method. Percentage of sodium has been calculated by the Eq. 1 as given below in $\mathrm{meq} / \mathrm{L}$,
$(\% \mathrm{Na})=\frac{\left(\mathrm{Na}^{+}+\mathrm{K}^{+}\right)}{\left(\mathrm{Ca}^{2+}+\mathrm{Mg}^{2+}+\mathrm{Na}^{+}+\mathrm{K}^{+}\right)} \times 100$
Equation 1

Page $3 / 18$ 
Following Eq. 2 was used to determine the Sodium Adsorption Ratio (SAR) in meq/L,

$\mathrm{SAR}=\frac{N a^{+}}{\sqrt{\left(C a^{2+}+M g^{2+}\right) / 2}}$

Equation 2

Cation and anion concentrations in geothermal water from different locations of South Part of Gujarat and West Coast Geothermal Province (WCGP) are as shown in Table 1 and Table 2, respectively.

Table 1

Physico-chemical parameters and major ion concentration in geothermal spring water from different sites in West Coast Geothermal Province (WCGP) of Maharashtra, India (Chandrasekhar et al. 2018)

\begin{tabular}{|c|c|c|c|c|c|c|c|c|c|c|c|c|c|c|c|}
\hline Sr.No. & Location & $\begin{array}{l}\text { Temp } \\
(\mathbb{\nabla C})\end{array}$ & $\mathrm{pH}$ & TDS & $\mathrm{Cl}^{-}$ & $\mathrm{SO}_{4}{ }^{2-}$ & $\mathrm{F}^{-}$ & $\begin{array}{l}\text { Conductivity } \\
(\mu \mathrm{S} / \mathrm{cm})\end{array}$ & $\mathrm{Na}^{+}$ & $\mathrm{K}^{+}$ & $\mathrm{Ca}^{2+}$ & $\mathrm{Mg}^{2+}$ & $\begin{array}{l}\mathrm{CO}_{3}^{2-} \\
\text { Hardness }\end{array}$ & $\mathrm{HCO}_{3}{ }^{-}$ & Salinity \\
\hline 1 & Unai 1 & 51.3 & 8.38 & 998 & 345 & 41.17 & 2.3 & 1475 & 158 & 13 & 168.34 & 5 & 260 & 126 & 623 \\
\hline 2 & Unai 2 & 55 & 7.86 & 1190 & 525 & 108.8 & 8 & 1840 & 324 & 15 & 52 & 17 & 84 & 42 & 948 \\
\hline 3 & Unai 3 & 56 & 8.12 & 1114 & 530 & 92.65 & 8.4 & 1662 & 340 & 10 & 64 & 4.86 & 96 & 42 & 957 \\
\hline 4 & $\begin{array}{l}\text { Saputara } \\
1\end{array}$ & 57 & 7.5 & 950 & 450 & 110 & 2.5 & 1500 & 215 & 9.8 & 65 & 1.2 & 98 & 41 & 950 \\
\hline 5 & $\begin{array}{l}\text { Saputara } \\
2\end{array}$ & 59 & 8.1 & 958 & 456 & 108 & 4.2 & 1490 & 230 & 10.5 & 60 & 2.8 & 90 & 43 & 960 \\
\hline 6 & $\begin{array}{l}\text { Saputara } \\
3\end{array}$ & 61 & 8.3 & 940 & 430 & 115 & 6.6 & 1530 & 250 & 9.6 & 67 & 3.5 & 94 & 44 & 955 \\
\hline
\end{tabular}

Table 2: Physico-chemical parameters and major ion concentration in geothermal spring water from different sites in West Coast Geothermal Province (WCGP) of Maharashtra, India (Chandrasekhar et al. 2018)

\begin{tabular}{|c|c|c|c|c|c|c|c|c|c|c|c|c|}
\hline Sr.No & Location & $\begin{array}{l}\text { Temp } \\
\left({ }^{\circ} \mathrm{C}\right)\end{array}$ & $\mathrm{pH}$ & Conductivity $(\mu \mathrm{S} / \mathrm{cm})$ & TDS & $\mathrm{Na}^{+}$ & $\mathrm{K}^{+}$ & $\mathrm{Ca}^{2+}$ & $\mathrm{Mg}^{2+}$ & $\mathrm{Cl}^{-}$ & $\mathrm{HCO}_{3}$ & $\mathrm{SO}_{4}^{2-}$ \\
\hline 1 & Koknere & 44 & 7.80 & 7340 & 4698 & 520 & 22.6 & 1106 & 6.1 & 2842 & 55 & 92 \\
\hline 2 & Padusapada & 43 & 8.69 & 2872 & 1838 & 409 & 17.8 & 193 & 0.1 & 925 & 5 & 136 \\
\hline 3 & Sativili & 57 & 8.73 & 2881 & 1844 & 421 & 18.3 & 175 & 0.04 & 875 & 10 & 123 \\
\hline 4 & Ganeshpuri & 60 & 8.60 & 2332 & 1492 & 322 & 14.0 & 155 & 0.1 & 725 & 5 & 124 \\
\hline 5 & Akloli & 50 & 8.56 & 3910 & 2502 & 448 & 19.5 & 402 & 0.1 & 1345 & 15 & 148 \\
\hline 6 & Pali & 48 & 6.54 & 4730 & 3027 & 427 & 18.6 & 582 & 0.5 & 1690 & 10 & 136 \\
\hline 7 & Dasgaon & 45 & 6.93 & 1858 & 1189 & 231 & 10.1 & 152 & 0.1 & 486 & 20 & 280 \\
\hline 8 & Mandangad & 55 & 7.98 & 2979 & 1907 & 430 & 18.7 & 185 & 0.3 & 1090 & 15 & 111 \\
\hline 9 & Unhavre-Farare & 72 & 7.68 & 3560 & 2278 & 521 & 22.7 & 223 & 0.3 & 1305 & 20 & 157 \\
\hline 10 & Aravali & 44 & 8.76 & 863 & 552 & 182 & 6.60 & 12.7 & $<$ & 218 & 25 & 90.9 \\
\hline 11 & Tural 1 & 65 & 7.67 & 1527 & 977 & 227 & 9.86 & 63.1 & 1.0 & 441 & 40 & 119 \\
\hline 12 & Tural 2 & 53 & 7.8 & 1466 & 938 & 220 & 9.57 & 62.5 & 0.3 & 437 & 40 & 102 \\
\hline 13 & Rajwadi & 55 & 8.2 & 1494 & 956 & 224 & 9.74 & 58.3 & 0.5 & 369 & 40 & 117 \\
\hline 14 & Anjaneri-Math & 40 & 8.64 & 2037 & 1304 & 324 & 14.1 & 84.2 & 0.1 & 540 & 10 & 275 \\
\hline 15 & Rajapur-Unhale & 43 & 7.54 & 524 & 335 & 72.4 & 3.2 & 26.6 & 7.0 & 16.3 & 260 & 4.72 \\
\hline
\end{tabular}

All values in $\mathrm{mg} / \mathrm{l}$ except specified

$<$ : Not detected.

\section{Results And Discussion}

\subsection{Water Quality Specification}

\subsubsection{Hydrogeochemistry}

The geothermal water from Unai and Saputara is slightly alkaline in nature as its $\mathrm{pH}$ ranges between 7.5-8.38 (Table 1). The pH value range of geothermal water from various locations of West Coast Geothermal Province (WCGP) is 6.5-8.7 which is also moderately alkaline in nature (Table 2). Temperature range of geothermal water from Unai and Saputara is $51-61^{\circ} \mathrm{C}$. It does not show any major deviation, temperature varies within a range of $1-10^{\circ} \mathrm{C}$ for all 
six thermal springs. However, temperature of geothermal water from various locations of WCGP varies from $40-72^{\circ} \mathrm{C}$ which indicates a significant variation. A total Dissolved Solids (TDS) concentration of geothermal water from Unai and Saputara ranges from 940 to 1190 mg/l. In geothermal water of WCGP, Total Dissolved Solids (TDS) concentrations varied from 335-4698 mg/l which is very high. Permissible limit for TDS in absence of any alternate source is $2000 \mathrm{mg} / \mathrm{l}$ (BIS 2012). But water having TDS concentration higher than $900 \mathrm{mg} / \mathrm{l}$ is less acceptable for drinking. Therefore, after desalination this water will be drinkable and it will also be useful for other societal and industrial purposes. In Unai and Saputara geothermal spring water chloride concentrations varies from 345 to $530 \mathrm{mg} / \mathrm{l}$ which is due to the dilutions of deep thermal water. The chloride concentration in geothermal water of WCGP is varied from 16.3 to $2842 \mathrm{mg} / \mathrm{l}$ as shown in Table 2. This is because of interaction of water with saline constituents. The sulfur content of spring water of Unai and Saputara is ranged from moderate to high 41-115 mg/l which indicates combination of volcanic gases with the thermal waters (Zimik et al. 2017). In thermal water of WCGP the sulfur concentration is 4.72 to $280 \mathrm{mg} / \mathrm{l}$ which shows dissolution of sulfur-containing minerals. High chloride concentration is damaging for metallic pipes, structure, and growing plants as well. It is observed that high sulfur content can cause plant aberration and can have injurious effects on plant nutrition. High sulfur concentration can cause corrosion of pipes. Sodium concentration in spring water of Unai and Saputara is ranging from 158 to $340 \mathrm{mg} / \mathrm{l}$ and in thermal water of WCGP is varies from 72.4 to $521 \mathrm{mg} / \mathrm{l}$. It shows that water is passing in deep and it might be a high enthalpy geothermal reservoir (Shah et al. 2019a). In Unai and Saputara geothermal water, sodium and chloride concentrations are quite high in compare to calcium, magnesium, and potassium. Bicarbonate concentration varies between 41 to $126 \mathrm{mg} / \mathrm{l}$. Geothermal water in Unai and Saputara indicates salinity between 623 to $960 \mathrm{mg} / \mathrm{l}$ which is low to moderate saline. In case of WCGP, sodium and chloride concentrations are high as well and calcium, magnesium, potassium concentrations are less. This is due to contact of basalt with sea water at high temperatures (Chandrasekhar et al. 2018). In koknere, the $\mathrm{Na} / \mathrm{Cl}$ ratio is 0.1829697 which is $<1$ and it shows that these dissolve salts might be of marine origin like fossil seawater, dissolution of marine evaporites, and deep motion of modern seawater. Low concentration of carbonate and bicarbonate in thermal water of Unai and Saputara indicate that from deeper levels water has upsurged. It is affected by the development water chemistry from the deeper grainy layer below the trappean flows (Sharma 2013). For drinking water, the permissible limit of fluoride is $1.5 \mathrm{mg} / \mathrm{l}$ and in Unai and Saputara spring water high concentration of fluoride has been observed i.e., 2.3 to $8.4 \mathrm{mg} / \mathrm{l}$. It makes water unfit for drinking purposes because high fluoride concentration can cause diseases like fluorosis. Fluoride concentration beyond $4 \mathrm{mg} / \mathrm{l}$ could be hazardous (BIS 2012). This high concentration is due to the contact of water with subsurface mica and apatite bearing rocks (WHO 2004). It can be considered that higher flow gradients which heat the water is being created by tectonic movement and mantle upliftment this water is upsurge back to the surface as it reaches its boiling temperature (Sircar et al. 2015).

\subsection{Hydrochemical facies}

Areal distribution and Hydrochemical evolution can be understood by plotting graphs of groundwater main dissolved components.

\subsubsection{Piper plot}

Piper 1944 had proposed one tri-linear plotting method which is the most widely utilized method for studying geochemical facies of groundwater. This plot allows clustering of data points to show samples which have same constitutions (Sankaran et al. 2015). The diamond plot is at the center and it is merged by two tri-linear plots that are on the two sides of the diamond. On the basis of supremacy in ion concentration dissimilar quadrants of diamond show the dissimilar kind of water as shown in Fig. 2a. Figure 2a shows the depiction of the results obtained from Unai and Saputara on the piper diagram. From figure it can be seen that $U_{2}, U_{3}$, and $S_{2}$ fall in Sodium Chloride water region while $U_{1}, S_{1}$, and $S_{3}$ come under Calcium Sulphate supremacy water region. Figure $2 \mathrm{~b}$ represents the piper diagram of WCGP Maharashtra, India. In WCGP, Koknere, Unhavre-Farare, Akloli, Mandangad, Pali, Sativili, and Padusapada fall in Sodium Chloride water region while Tural 1, Tural 2, Rajwadi, Anjaneri-Math, Dasgaon, and Ganeshpuri fall in Calcium Sulphate water region.

\subsubsection{Extended Durov plot}

The geochemical process which alters the groundwater quality can be disclosed by Durov (1948) plot (Lloyd and Heathcoat, 1985). In extended Durov plot, $\mathrm{pH}$ and TDS plots are included to the downside and right side of the diagram. In Durov diagram there are two tri-linear plots of cations and anions. The Hydrochemical process such as dissolution or precipitation and type of water like $\mathrm{NaCl}$ or $\mathrm{CaCO}_{3}$ will be identify by point of intersection of lines from trilinear plots of the similar water sample in the binary plot. In Unai and Saputara, Higher concentration of Ca and $\mathrm{HCO}_{3}{ }^{-}+\mathrm{CO}_{3}{ }^{2-}$ and lower concentration of $\mathrm{NaCl}$ was observed in $\mathrm{U}_{1}, \mathrm{~S}_{1}$, and $\mathrm{S}_{3}$ in comparison of $\mathrm{U}_{2}, \mathrm{U}_{3}$, and $\mathrm{S}_{2}$ as shown in Fig. 3a. Higher concentration of $\mathrm{Ca}$ and $\mathrm{HCO}_{3}{ }^{-}$was observed in Koknere and Rajpur-Unhale compare to other regions in WCGP. In Unhavre-Farare $\mathrm{NaCl}$ concentration is quite high which is represented in Fig. 3b. Piper and Extended Durov plots are showing similar conditions of cations and anions in both regions but there are many other features which can affect the geochemistry of groundwater hence several other plots and graphs should be combined to find the conclusion.

\subsubsection{Schoeller plot}

The semi-logarithmic illustration of the concentrations of major ionic constituents present in the water is known as a Schoeller diagram (Schoeller, 1961). The anions and cations present in the water samples have taken on the X-axis and their concentrations have been plotted on $\mathrm{Y}$-axis for all the samples. Different ions present in various samples can be compared with the help of this plot. From Fig. 4 a it can be seen that $U_{2}$ and $U_{3}$ are having great similarity and $\mathrm{U}_{1}$ is different from other two. $\mathrm{S}_{1}, \mathrm{~S}_{2}$, and $\mathrm{S}_{3}$ are having almost similar pattern. In all the samples supremacy of $\mathrm{Na}+\mathrm{K}$ cations and $\mathrm{Cl}$ anions is there. Figure $4 \mathrm{~b}$ represents the major ion concentration present in the water sample from WCGP. In Koknere, dominance of $\mathrm{Na}+\mathrm{Ca}$ cation and $\mathrm{Cl}$ anion were observed.

\subsubsection{Stiff Diagram}


The chemical analyses of geothermal water can be done by graphical representation which is defined as a stiff diagram. Hydrogeologists and geochemists are widely use stiff diagram to depict the main ion composition of a water sample. In this diagram one vertical zero axis and four similar horizontal axis are plotted. These four horizontal axis expanding on either side of a vertical axis which generates a polygonal shape (Stiff 1951). The ion concentrations have taken in meq/l. In the stiff diagram, left side of the zero axis cations have plotted and right side of the zero axis anions have plotted. Comparison of ion concentrations present in water samples from the different regions can be done by plotting stiff diagram. Stiff diagram for South Part of Gujarat and West Coast Geothermal Province is as shown ion Fig. 5.

\subsubsection{Gibbs plot}

With the help of Gibbs diagram water chemistry and its chemical formation from the consequent aquifers such as evaporation rate, precipitated chemistry, and rock form chemistry can be understood (Ronald J 1970). In order to understand nature of geothermal water chemistry from different regions of Gujarat and Maharashtra, Gibbs difference $\mathrm{Cl}^{-} /\left(\mathrm{Cl}^{-}+\mathrm{HCO}_{3}{ }^{-}\right)$i.e. anions and Gibbs variance $\mathrm{Na}^{+} /\left(\mathrm{Na}^{+}+\mathrm{Ca}^{2+}\right)$ i.e. cations of water samples have been plotted discretely against respective values of TDS in mg/l. From TDS Vs Na$/\left(\mathrm{Na}^{+}+\mathrm{Ca}^{2+}\right.$ ) (Fig. 6a) it can be observed that $\mathrm{U}_{2}$ and $\mathrm{U}_{3}$ have shown evaporation dominance and $\mathrm{U}_{1}, \mathrm{~S}_{1}, \mathrm{~S}_{2}$, and $\mathrm{S}_{3}$ have shown rock dominance in geothermal water composition. TDS Vs $\mathrm{Cl}^{-} /\left(\mathrm{Cl}^{-}+\mathrm{HCO}_{3}{ }^{-}\right)$is similar to the TDS Vs $\mathrm{Na}^{+} /\left(\mathrm{Na}^{+}+\mathrm{Ca}^{2+}\right)$. In the case of WCGP, TDS Vs Na $/\left(\mathrm{Na}^{+}+\mathrm{Ca}^{2+}\right)$ (Fig. 6b) has indicated that Koknere, Pali, Akloli, Padusapada, Unhavre-Farare, Mandangad, Dasgaon, Ganeshpuri, Sativili, and Anjaneri-Math have shown evaporation dominance and Tural 1, Tural 2, Rajwadi, Aravali, and RajpurUnhale have shown rock dominance in geothermal water composition. TDS Vs $\mathrm{Cl}^{-} /\left(\mathrm{Cl}^{-}+\mathrm{HCO}_{3}^{-}\right)$is almost similar to the TDS Vs $\mathrm{Na}^{+} /\left(\mathrm{Na}^{+}+\mathrm{Ca}^{2+}\right)$ except Dasgaon. In this plot Dasgaon has shown rock dominance. In the case of alluvial plains, the groundwater chemistry is majorly dominated by rock-water interference occurrence (Alam 2014). From Fig. 6a and Fig. 6 bit can be observed that none of the water samples have precipitation dominance. Precipitation dominance indicates that samples have taken during monsoon. Geothermal water of Unai and Saputara is having TDS concentration near $1000 \mathrm{mg} / \mathrm{l}$ thus it can be use for societal purposes while water from WCGP is having high concentration of TDS > $1000 \mathrm{mg} / \mathrm{l}$ which is not suitable for any purposes. After desalination of this water it can be used for various purposes like drinking, irrigation, domestic, and industrial.

\subsubsection{Ternary plot}

The proportion of major ions presented in geothermal spring water is represented by Ternary diagram (Giggenbach, 1991). Two different Ternary diagrams of cations and anions have plotted with a view to differentiate fluids from various sources. Ternary diagram for cation is combining Na-K with $\mathrm{K}-\mathrm{Mg}$. In Unai and Saputara, all locations are having water with lower concentration of $\mathrm{Mg}$. All the points fall on the Na-K line since there is very less concentration of $\mathrm{Mg}$ is present as shown in Fig. 7a. Similarly, in WCGP concentration of $\mathrm{Mg}$ is very less and $\mathrm{Na}$ and $\mathrm{K}$ concentrations are comparatively very high as depicted in Fig. 7b. Therefore, all the points are fall on the Na-K line. Figure 7c represents the major anion concentration present in the water sample from Unai and Saputara. This type of ternary plot is used to categorize the forms of geothermal water of a field under study. There are four types of geothermal water: Mature water, volcanic water, steam heated water, and peripheral water which can be discriminated from the ternary diagram.U1, U2, $\mathrm{U}_{3}$, S1, $\mathrm{S}_{2}$, and $\mathrm{S}_{3}$ come under $\mathrm{Cl}$ rich domain of geothermal water and which shows that it is mature water. All the points are fall on the $\mathrm{Cl}_{-} \mathrm{SO}_{4}$ line because $\mathrm{HCO}_{3}$ concentration is comparatively low. In geothermal water of $\mathrm{U} 2$ andU $\mathrm{U}_{3}$ supremacy of $\mathrm{SO}_{4}$ over $\mathrm{HCO}_{3}$ as compared to $\mathrm{U}_{1}$ indicates that geothermal water may have been blended with marginal steam heated water or it may be due to interaction of water with sulfur bearing environment during water-rock interaction. High chloride content of water is suggesting influence of seawater intermixing with thermal fluids. Distribution of anion concentration in geothermal water of WCGP is as shown in Fig. 7d.Due to the high $\mathrm{Cl}$ concentration, most of the thermal spring waters plot near the chloride apex. Spring waters of Dasgaon, Anjneri-Math, and Aravali are having high $\mathrm{SO}_{4} / \mathrm{Cl}$ ratios and hence it is somewhat shifted towards the $\mathrm{SO}_{4}$ field indicates dissolution of sulfur bearing minerals. Thermal springs $(1,6,8,9,3$,and 4 from Table 2$)$ on the northern part of the study area drop on the $\mathrm{Cl}_{-} \mathrm{SO}_{4}$ line which has shown high concentration of $\mathrm{Cl}$ due to seawater mixing. Thermal springs (10,14, 13, and 11 from Table 2) pointing towards two different saline sources. In WCGP, all locations come under $\mathrm{Cl}$ rich domain of geothermal water and which shows that it is mature water except Rajpur-Unhale (15 from Table 2). It falls on the $\mathrm{Cl}-\mathrm{HCO}_{3}$ line and it is peripheral water as shown in the Fig. 7d.

\subsubsection{Wilcox diagram}

Groundwater suitability for irrigation purposes can be analyzed very effectively with the help of Wilcox diagram (Wilcox, 1955). Percentage of sodium $(\% \mathrm{Na})$ Vs. Conductivity graph has been plotted for geothermal water samples from Unai and Saputara as shown in Fig. 8c. Geothermal water from Unai 1 has fallen under the range of good to permissible and Saputara 1, 2, \& 3 have fallen under the range of permissible to doubtful. Unai 2 and Unai 3 have fallen on the border of permissible to doubtful and doubtful to unsuitable as shown in Fig. 8c. Therefore, geothermal water of Unai 1 is suitable for drinking and irrigation purposes. Water from Saputara 1, 2, \& 3 and Unai 2 \& 3 are not suitable for drinking but it can be used for irrigation, domestic, and industrial purposes. No samples from South part of Gujarat have fallen under unsuitable that means geothermal water of this region is suitable for various purposes. As shown in Fig. 8d Rajapur-Unhale has fallen within the range of excellent to good means it can be directly used for drinking and irrigation purposes. Tural 1, Tural 2, Rajwadi, and Dasgaon have fallen under the range of permissible to doubtful and Aravali, Anjaneri-Math, Ganeshpuri, Sativili, Padusapada, and Mandangad have come under the range of Doubtful to unsuitable which indicates that it is not suitable for drinking purposes but it can be used for irrigation. Unhavre-Farare, Akloli, and Pali have fallen within the range of unsuitable (Fig. 8d) and thus water from these regions require pre-treatment before using it for drinking and irrigation.

In the Wilcox log plot, Sodium Adsorption Ratio (SAR) has plotted on the Y-axis and Conductivity has plotted on the X-axis. The Conductivity has represented in a log scale. This plot is also helpful in testing suitability of water for irrigation. From Fig. 8ait can be seen that S1, S2, S3, and S4 are sodium hazard classes and C1, C2, C3, and C4 are salinity hazard classes. Unai 1 has fallen within the range of S1-C3 (Fig. 8a); it shows that it can be used for drinking and irrigation purposes. All other locations i.e. Unai $2 \& 3$ and Saputara 1, 2, \& 3 have fallen within the range of S2-C3 and it indicates that it is 
suitable for irrigation, domestic, and industrial purposes but not suitable for drinking purposes. In the case of WCGP, geothermal water of Rajapur-Unhale has fallen within the range of S1-C2 and which shows that it is suitable for drinking and for agricultural purposes as shown in Fig. 8b. Anjaneri-Math, Dasgaon, Rajwadi, Tural 1, and Tural 2 have fallen under the range of S2-C3 means it can be used for all other purposes except drinking. Aravali has come under the range of S3-C3 which is showing that it cannot be used for drinking purposes. Ganeshpuri, Padusapada, Sativili, Akloli, and Pali have fallen under the range of S2-C4 (Fig. 8b), which indicates that geothermal water of these regions require pre-treatment before using it for various purposes. Unhavre-Farare has come within the range of S3-C4 (Fig. 8b) which is also very high hence it requires pre-treatment before its use for drinking and irrigation.

\subsubsection{Spatial distribution plot}

Spatial distribution curves for various locations in South part of Gujarat and West Coast Geothermal Province are as shown in Figs. 9 and 10, respectively.

\section{Conclusion}

This study shows that geothermal spring water of both South part of Gujarat and West Coast Geothermal Province is enriched with ions like Sodium, Potassium, Calcium, Chloride, and Sulphate. The study of geothermal water of Unai and Saputara shows low to moderate Na-Cl content. Geothermal spring water of Unai 2 and Unai 3 are having high concentration of TDS concentration and it needs to be reducing for utilize these spring waters for drinking and irrigation. Water from Unai 1 is the most suitable for drinking and irrigation purposes. Water from these regions may be passed through different dissolution-precipitation processes or contamination from other sources that resulted into an improper evaluation of its chemistry. For WCGP region it can be said that almost every geothermal spring waters are $\mathrm{Na}(\mathrm{Ca})-\mathrm{Cl}$ or $\mathrm{Ca}(\mathrm{Na})-\mathrm{Cl}$ type only few spring waters are $\mathrm{Na}-\mathrm{Cl}\left(\mathrm{SO}_{4}\right)$ type. $\mathrm{Thermal}$ spring water of Rajapur-Unhale is only $\mathrm{Na}-\mathrm{HCO}_{3}$ type. Spring waters having high salinity are confined to the northern part of the study area. Water from the northern part is more saline which indicates a deep movement of seawater with the thermal water. Less concentration of magnesium, potassium, and bicarbonate and high concentration of calcium, sodium, and chloride is a sign of basalt seawater contact at high temperature. Among all the locations in WCGP, Koknere is having the highest value of TDS concentration which indicates that it requires desalination treatment before using it for drinking, irrigation and all other purposes. $\mathrm{Na} / \mathrm{Cl}$ ratio in Koknere is 0.1829697 which is $<1$ which indicates that source of these dissolve salts may be from marine like seawater and deep motion of modern seawater. All the different plots for both of the regions are showing same indication of high ion concentrations specially $\mathrm{Na}-\mathrm{Cl}$. Geothermal water of Unai and Saputara can be utilized directly for various purposes without any treatment but spring water of WCGP require some pre-treatment before its use for different purposes.

\section{Declarations}

\section{Funding}

Not Applicable

\section{Conflicts of interest}

Authors have no conflict of interest

\section{Authors' contributions}

AS and KY have prepared the manuscript. NB and HO have worked on the data processing. AS and KY have worked on the interpretation of data.

\section{References}

1. Alam F (2014) Evaluation of hydrogeochemical parameters of groundwater for suitability of domestic and irrigational purposes: a case study from central Ganga Plain, India. Arab J Geosci 7:4121-4131. https://doi.org/10.1007/s12517-013-1055-6

2. Armijo CF (2012) Water journeys II. Granada's spas and springs through travellers' and hydrologists' eyes. Solprint, Madrid.

3. BIS ISDWS (2012) Bureau of Indian Standards. New Delhi.

4. Biswas SK (1987) Regional tectonic framework, structure and evolution of the western marginal basins of India. Tectonophysics 135:307-327. https://doi.org/10.1016/0040-1951(87)90115-6

5. Chandrasekhar T, Minissale A, Vaselli O, et al (2018) Understanding the evolution of thermal fluids along the western continental margin of India using geochemical and boron isotope signatures. Geothermics 74:197-209. https://doi.org/10.1016/j.geothermics.2018.03.007

6. Giggenbach WF, Goguel RL (1989) Collection and the analysis of the geothermal and volcanic waters and gas discharges. Pentone.

7. Giggenbach WF (1991) Chemical techniques in geothermal exploration. Application of geochemistry in geothermal reservoir development.

8. Gupta BK (2014) Central Ground Water Board, Ministry of Water Resources, Government of India. Centre for Environment Education. Gujarat Groundwater Brochure.

9. Jahangiry Fard M, Amanipoor H, Battaleb-Looie S, Ghanemi K (2019) Evaluation of effect factors on water quality of Karun River in downstream and lake of the Gotvand-e-Olya Dam (SW Iran). Appl Water Sci 9:1-14. https://doi.org/10.1007/s13201-019-1040-7

10. Lloyd JW, Heathcote JAA (1985) Natural inorganic hydrochemistry in relation to ground water. 
11. Low U, Absar A, Duraiswami R, Singh A (2020) Geophysical exploration of Tural-Rajwadi group of hot springs, West Coast Geothermal Province, Maharashtra, India and its implications. Geothermics 88:101874. https://doi.org/10.1016/j.geothermics.2020.101874

12. Monterio AJ, Duraiswami RA, Pujari SJ, et al (2019) Petrophysical variations within the basaltic lava flows from Tural-Rajawadi hot springs, Western India and their bearing on the viability of low-enthalpy geothermal systems. IOP Conf Ser Earth Environ Sci 249:. https://doi.org/10.1088/1755$1315 / 249 / 1 / 012004$

13. Organization mondiale de la santé, WHO-Work programme, Światowa Organizacja Zdrowia, World Health Organization, WHO, \& World Health Organisation Staff (2004) Guidelines for drinking-water quality. $3^{\text {rd }}$ edn. Geneva, 1:1-515

14. Piper AM (1944) file:///C:/Users/gaurang bhai/Desktop/GC/stiff1951.pdf. Am Geophys union 914-928

15. Pujari SJ (2014) Subsurface geology, textural variations, and hydrothermal alteration in the basalt from Tural-Rajwadi borehole, West Coast geothermal field, India. Doctoral Dissertation, Department of Geology, University of Pune.

16. Rahimi L, Amanipoor H, Battaleb-Looie S (2019) Effect of salinity of irrigation water on soil properties (abadan plain, SW Iran). Geocarto Int 0:1-20. https://doi.org/10.1080/10106049.2019.1678678

17. Rao KM, Kumar MR, Rastogi BK (2015) Crust beneath the northwestern Deccan Volcanic Province, India: Evidence for uplift and magmatic underplating. J Geophys Res Solid Earth 120:3385-3405. https://doi.org/10.1002/2014JB011819

18. Rao PS, Singh AK, Rao CK (2012) Regional conductance map of Saurashtra and surrounding regions. Current Science 187-193

19. Rhodes DE (1980) APHA, AWWA, WEF. Standard Methods for exa- mination of water and wastewater. 22nd ed. Wa- shington: American Public Health Association; 2012, 1360 pp. ISBN 978-087553-013-0 http://www.standardmethods.org/. Library (Lond) s6-Il:335

20. Ronald J G (1970) Mechanisms Controlling World Water Chemistry. Science (80- ) 170:1088-1090

21. Sankaran S, Sundararajan N, Khadija S (2015) Geochemical analysis of groundwater samples in the vicinity of lakes and drainage network. J Geol Soc India 86:459-467. https://doi.org/10.1007/s12594-015-0333-1

22. Schoeller H (1967) Hydrodynamiquedans le karst. Chroniqued'hydrogeologie 10:7-21

23. Shah B, Kansara B, Shankar J, et al (2019a) Reckoning of water quality for irrigation and drinking purposes in the konkan geothermal provinces, Maharashtra, India. Groundw Sustain Dev 9:100247. https://doi.org/10.1016/j.gsd.2019.100247

24. Shah M, Pawar Y, Patel M, et al (2021) Comprehensive hydro-chemistry and geothermal water quality of Konkan, Maharashtra, India for sustainable industrial development. Groundw Sustain Dev 12:100518. https://doi.org/10.1016/j.gsd.2020.100518

25. Shah M, Sircar A, Shaikh N, et al (2019b) Comprehensive geochemical/hydrochemical and geo-thermometry analysis of Unai geothermal field, Gujarat, India. Acta Geochim 38:145-158. https://doi.org/10.1007/s11631-018-0291-6

26. Shah M, Sircar A, Varsada R, et al (2019c) Assessment of geothermal water quality for industrial and irrigation purposes in the Unai geothermal field, Gujarat, India. Groundw Sustain Dev 8:59-68. https://doi.org/10.1016/j.gsd.2018.08.006

27. Sharma N (2013) Physico-chemical characterization of the thermal spring waters occurring in Gujarat, India. CEGE report.

28. Singh HK, Chandrasekharam D, Trupti G, et al (2016) Potential Geothermal Energy Resources of India: A Review. Curr Sustain Energy Reports 3:80-91. https://doi.org/10.1007/s40518-016-0054-0

29. Sircar A (2017) Geothermal: Updates OVERVIEW OF GEOTHERMAL SURFACE

30. Sircar A, Shah M, Sahajpal S, et al (2015) Geothermal exploration in Gujarat: case study from Dholera. Geotherm Energy 3:1-25. https://doi.org/10.1186/s40517-015-0041-5

31. Stiff HA (1951) The Interpretation of Chemical Water Analysis by Means of Patterns. J Pet Technol 3:15-3. https://doi.org/10.2118/951376-g

32. Wilcox L (1955) Classification and use of irrigation waters. Departmetnt of Agriculture, US.

33. Yadav K, Sircar A (2019) Integrated 2D joint inversion models of gravity, magnetic, and MT for geothermal potentials: a case study from Gujarat, India. Model Earth Syst Environ 5:963-983. https://doi.org/10.1007/s40808-019-00582-2

34. Yadav K, Sircar A, Jani D, Bist N, Nirantare A, Mali N, Singh S (2021) Geochemical characterization of geothermal spring waters occuring in Gujarat, India. International Journal of Energy and Water Resources 0:1-14

35. Zimik H V., Farooq SH, Prusty P (2017) Geochemical evaluation of thermal springs in Odisha, India. Environ Earth Sci 76:1-12. https://doi.org/10.1007/s12665-017-6925-x

\section{Figures}




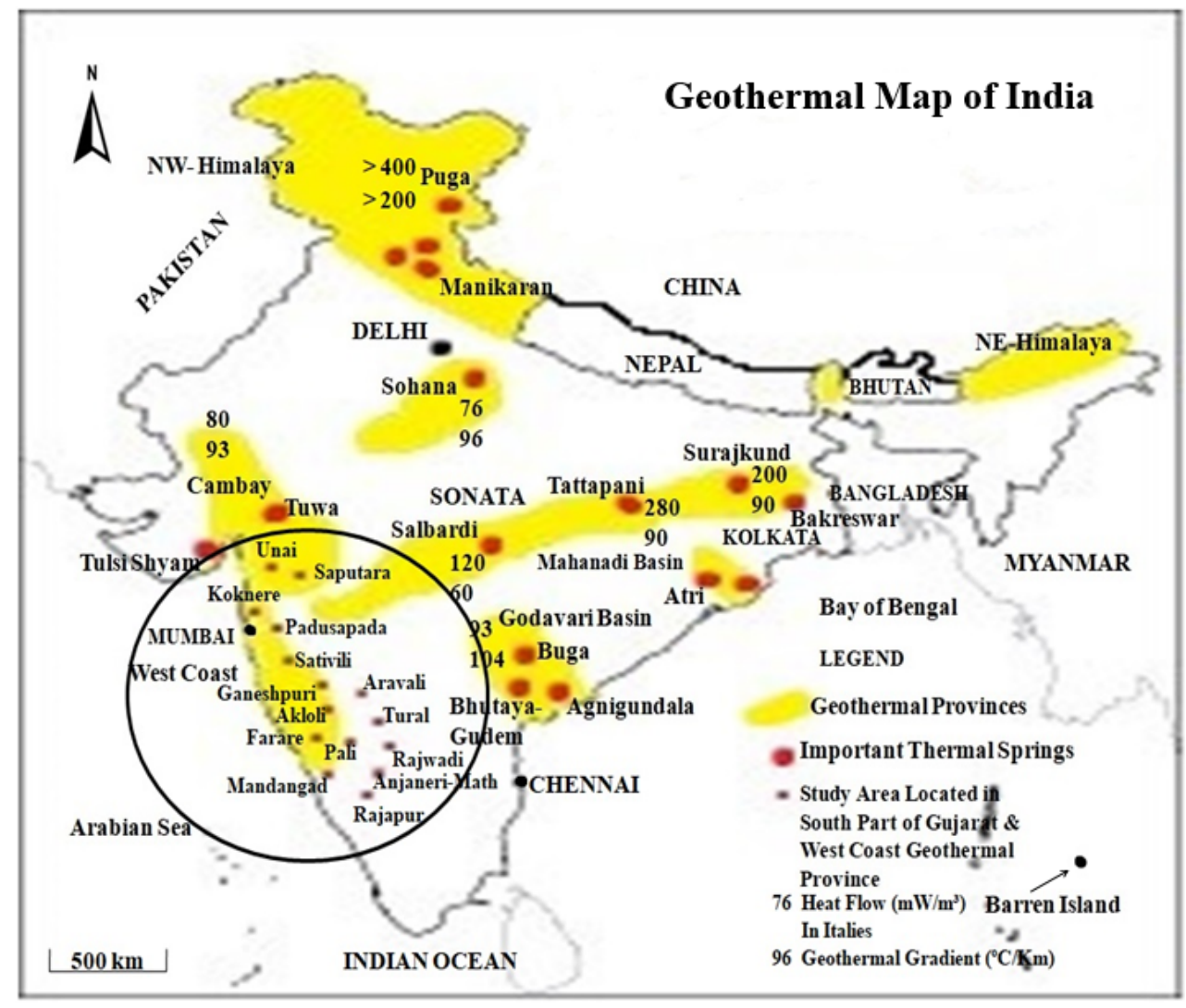

Figure 1

Geothermal provinces of India, showing South part of Gujarat and West Coast province by circle; Geothermal Spring sampling locations; Cross section of the Deccan flows indicating various configurations and locations of essential thermal springs (Singh et al. 2016) Note: The designations employed and the presentation of the material on this map do not imply the expression of any opinion whatsoever on the part of Research Square concerning the legal status of any country, territory, city or area or of its authorities, or concerning the delimitation of its frontiers or boundaries. This map has been provided by the authors. 


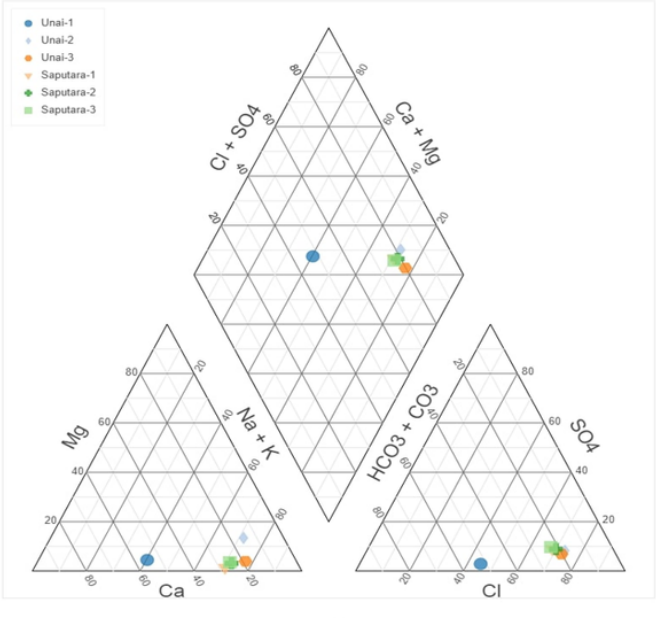

(a)

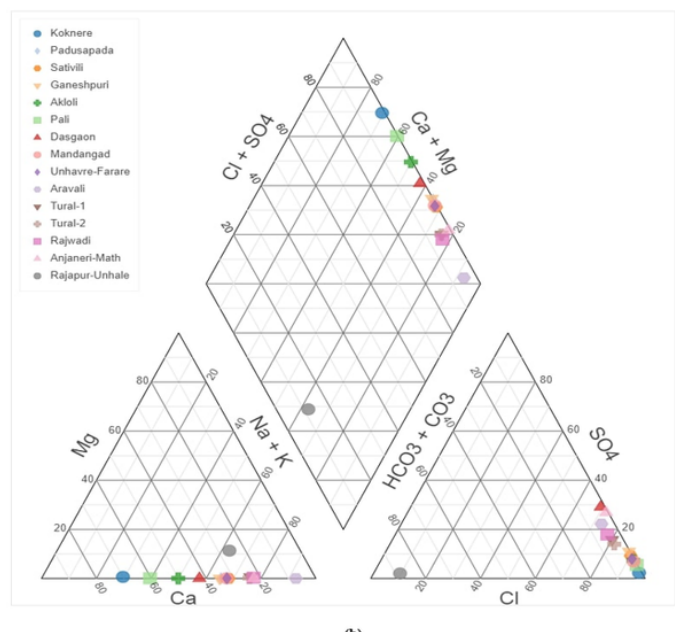

(b)

Figure 2

(a) Piper Diagram representing concentration of cations and anions in geothermal water of south part of Gujarat, India (Shah et al. 2019b) (b) Piper Diagram representing concentration of cations and anions in geothermal water of West Coast Geothermal Province, Maharashtra, India (Chandrasekhar et al. 2018) 


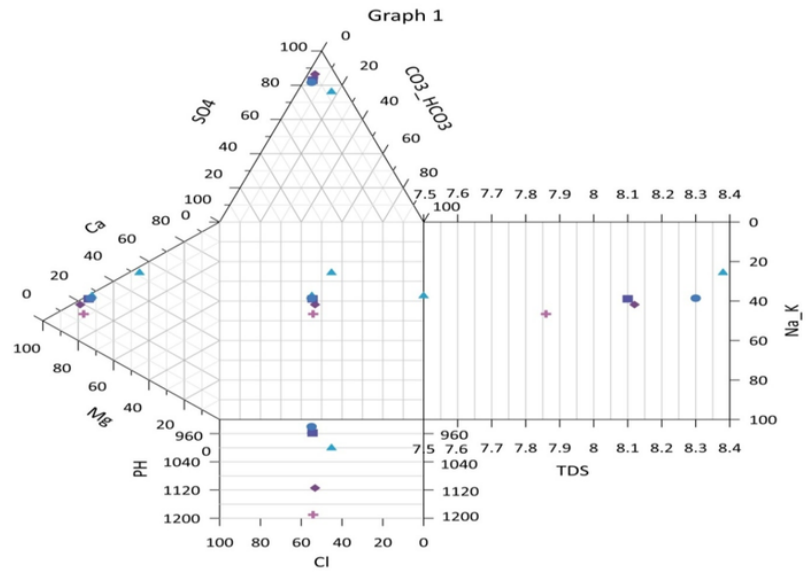

(a)

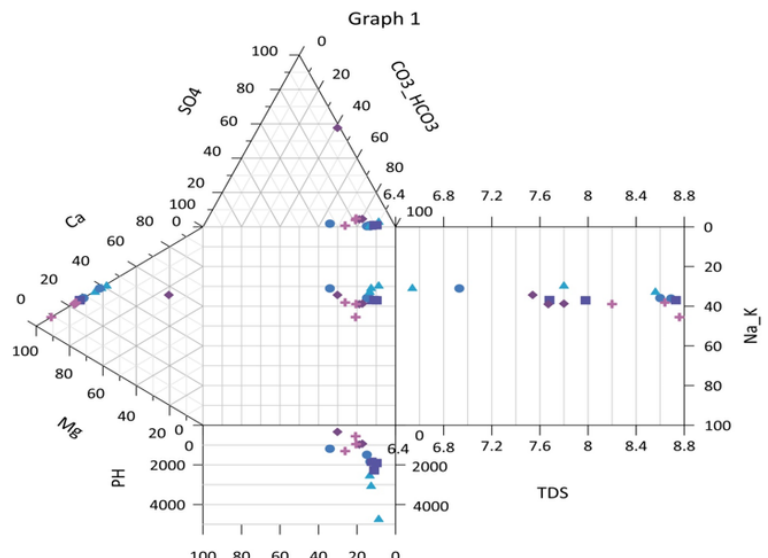

$\mathrm{Cl}$

(b)

Figure 3

(a) Extended Durov Diagram representing concentration of cations, anions, and TDS in geothermal water of south part of Gujarat, India (Shah et al. 2019b)

(b) Extended Durov Diagram representing concentration of cations, anions, and TDS in geothermal water of West Coast Geothermal Province, Maharashtra, India 


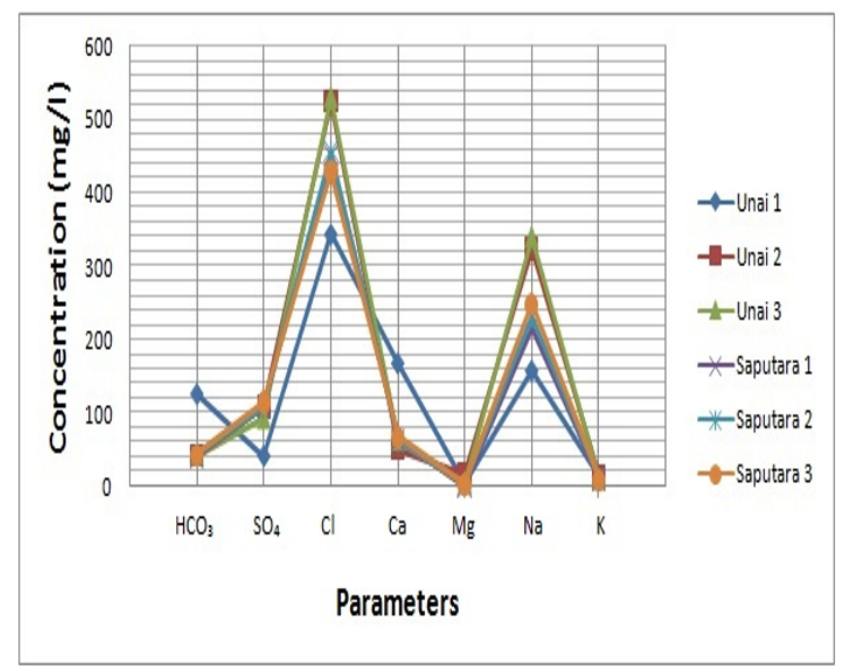

(a)

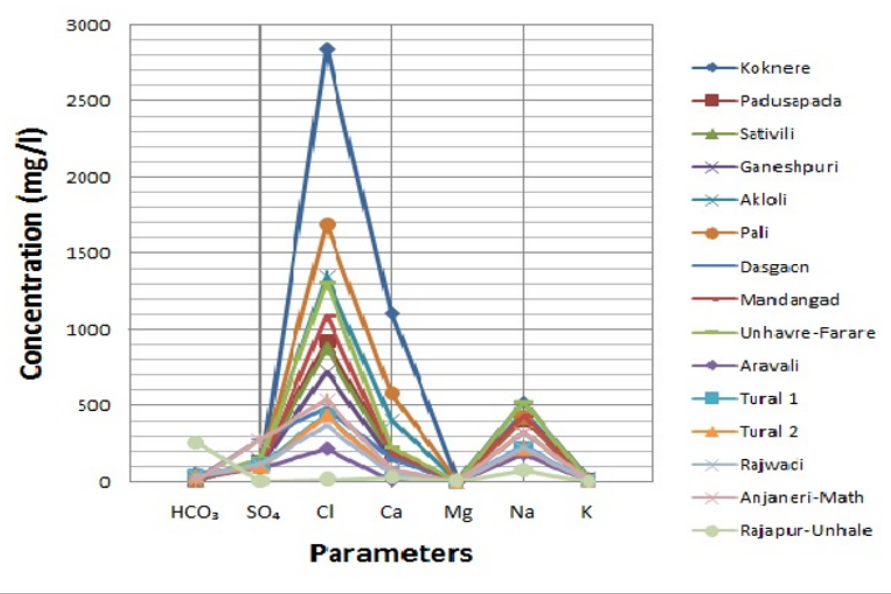

(b)

\section{Figure 4}

(a) Schoeller Diagram representing concentration of ions in geothermal water of south part of Gujarat, India (Shah et al. 2019b) (b) Schoeller Diagram representing concentration of ions in geothermal water of West Coast Geothermal Province, Maharashtra, India 


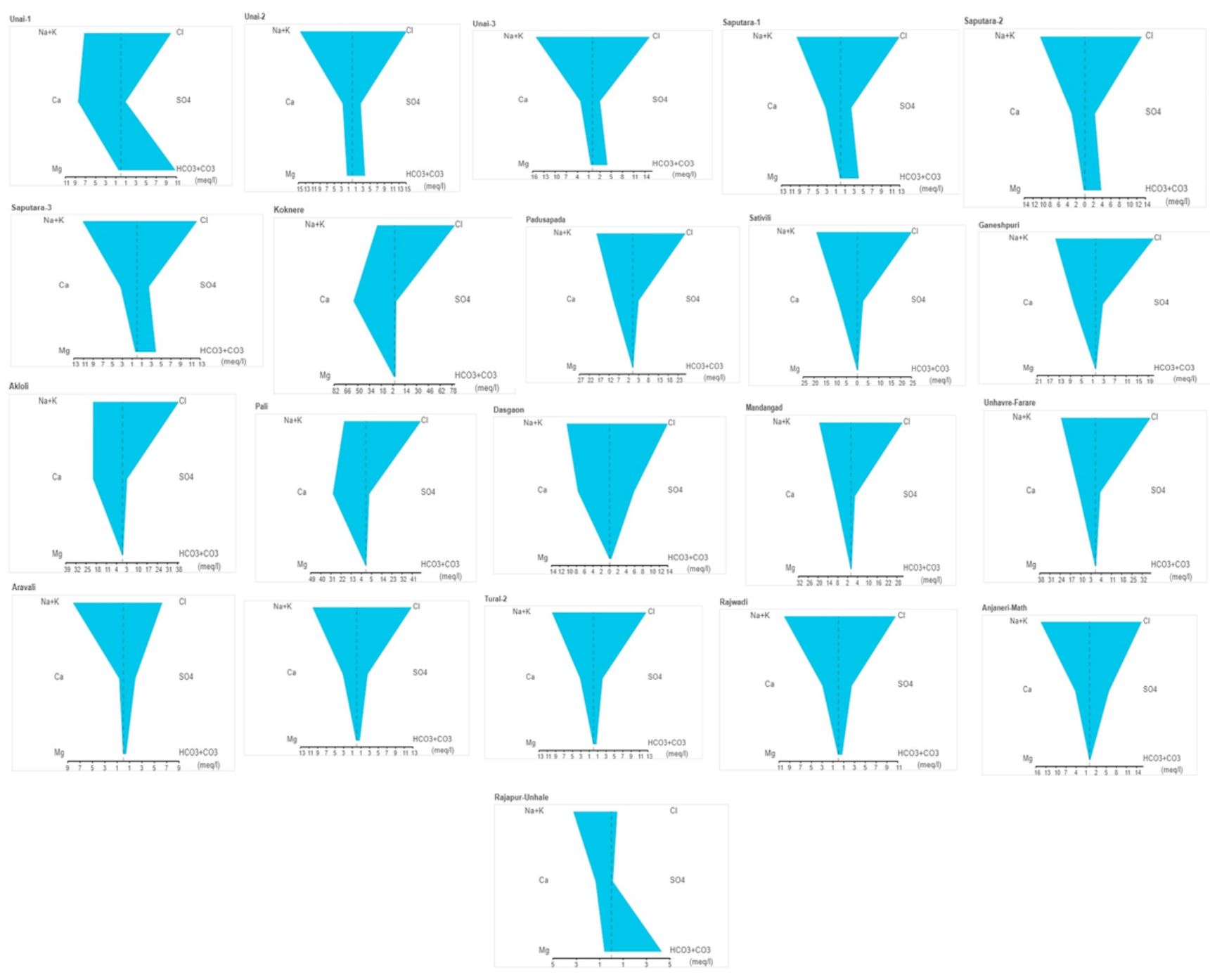

Figure 5

Representative Stiff Diagram of geothermal spring water of south part of Gujarat (Unai 1) Representative Stiff Diagram of geothermal spring water of south part of Gujarat (Unai 2) Representative Stiff Diagram of geothermal spring water of south part of Gujarat (Unai 3) Representative Stiff Diagram of geothermal spring water of south part of Gujarat (Saputara 1) Representative Stiff Diagram of geothermal spring water of south part of Gujarat (Saputara 2) Representative Stiff Diagram of geothermal spring water of south part of Gujarat (Saputara 3) Representative Stiff Diagram of geothermal spring water of West Coast Geothermal Province, Maharashtra (Koknere) Representative Stiff Diagram of geothermal spring water of West Coast Geothermal Province, Maharashtra (Padusapada) Representative Stiff Diagram of geothermal spring water of West Coast Geothermal Province, Maharashtra (Sativili) Representative Stiff Diagram of geothermal spring water of West Coast Geothermal Province, Maharashtra (Ganeshpuri) Representative Stiff Diagram of geothermal spring water of West Coast Geothermal Province, Maharashtra (Akloli) Representative Stiff Diagram of geothermal spring water of West Coast Geothermal Province, Maharashtra (Pali) Representative Stiff Diagram of geothermal spring water of West Coast Geothermal Province, Maharashtra (Dasgaon) Representative Stiff Diagram of geothermal spring water of West Coast Geothermal Province, Maharashtra (Mandangad) Representative Stiff Diagram of geothermal spring water of West Coast Geothermal Province, Maharashtra (Unhavre-Farare) Representative Stiff Diagram of geothermal spring water of West Coast Geothermal Province, Maharashtra (Aravali) Representative Stiff Diagram of geothermal spring water of West Coast Geothermal Province, Maharashtra (Tural-1) Representative Stiff Diagram of geothermal spring water of West Coast Geothermal Province, Maharashtra (Tural-2) Representative Stiff Diagram of geothermal spring water of West Coast Geothermal Province, Maharashtra (Rajwadi) Representative Stiff Diagram of geothermal spring water of West Coast Geothermal Province, Maharashtra (Anjaneri-Math) Representative Stiff Diagram of geothermal spring water of West Coast Geothermal Province, Maharashtra (Rajapur-Unhale) 

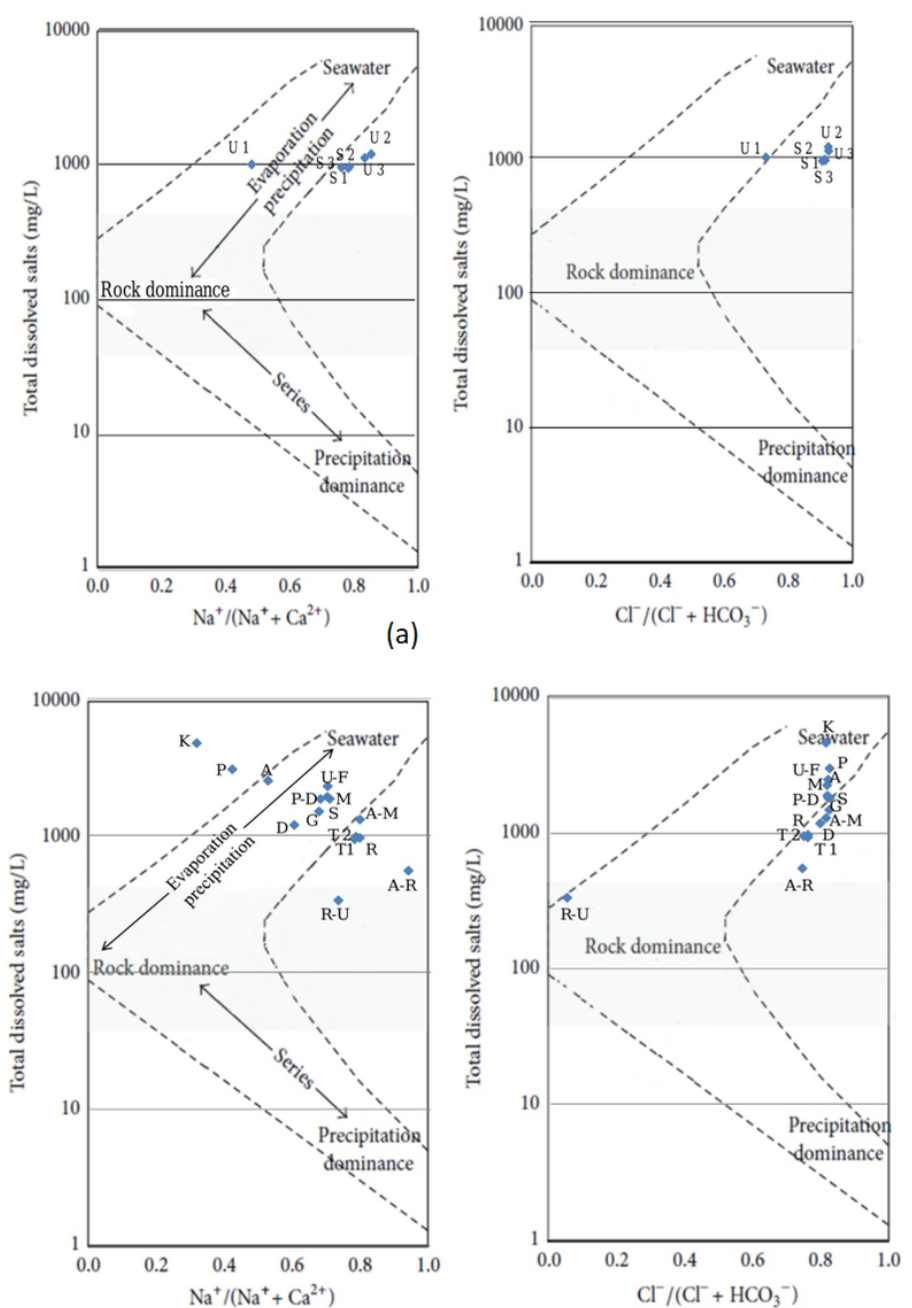

(b)

Figure 6

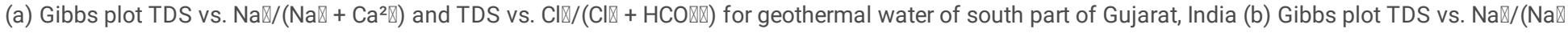
$\left.+\mathrm{Ca}^{2} \rrbracket\right)$ and TDS vs. $\mathrm{Cl} \nabla /(\mathrm{Cl} \nabla+\mathrm{HCO} \otimes)$ for geothermal water of West Coast Geothermal Province, Maharashtra, India 


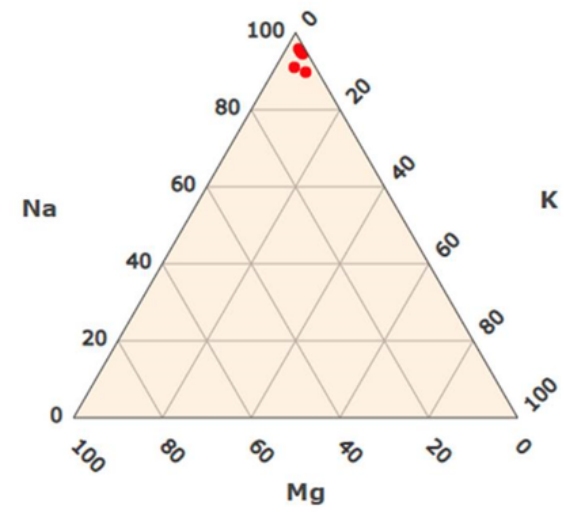

(a)

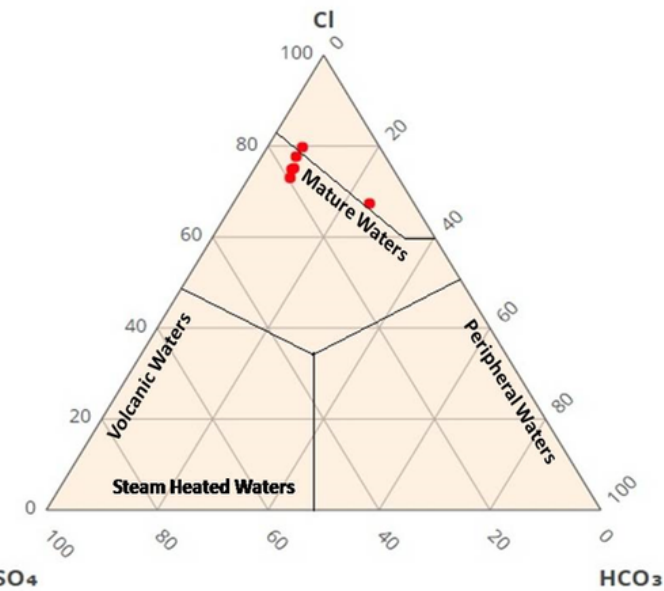

(c)

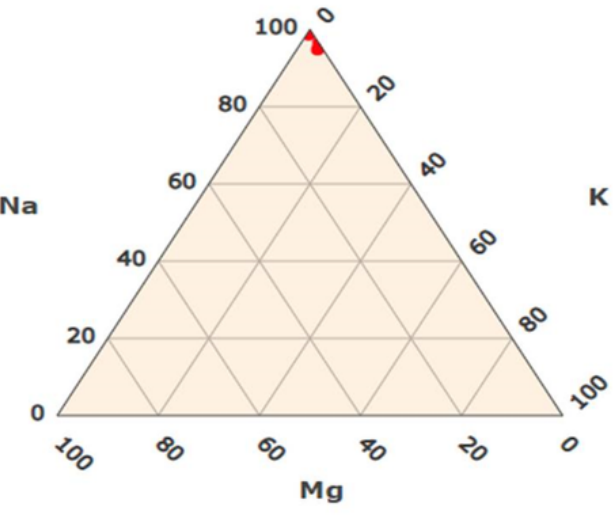

(b)

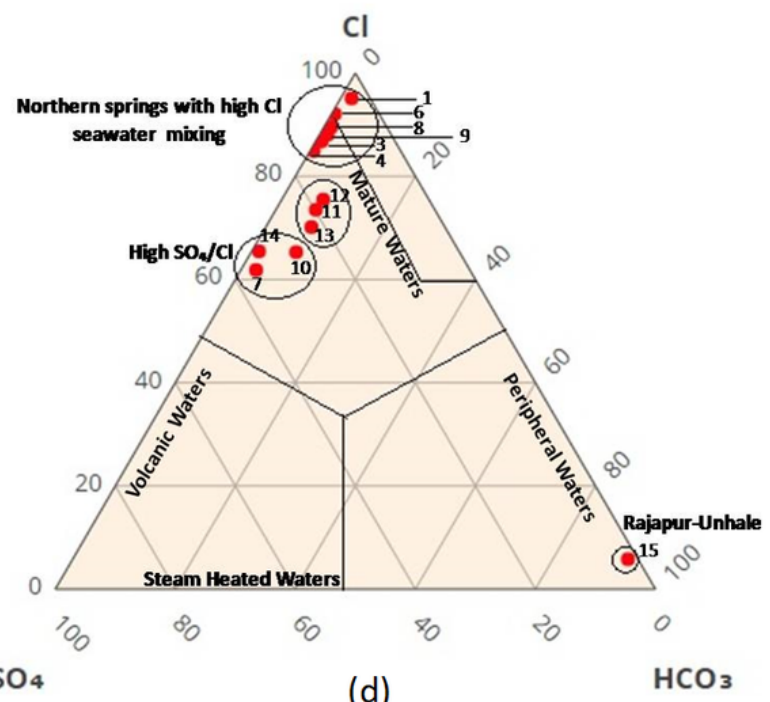

(d)

Figure 7

(a) Ternary Diagram representing concentration of cations (Na-Mg-K) in geothermal water of south part of Gujarat, India (Yadav et al. 2021) (b) Ternary Diagram representing concentrations of cations (Na-Mg-K) in geothermal water of West Coast Geothermal Province, Maharashtra, India (c) Ternary Diagram representing the concentration of anions (Cl-SO4-HCO3) in geothermal water of south part of Gujarat, India (Yadav et al. 2021) (d) Ternary Diagram representing concentration of anions (Cl-SO4-HCO3) in geothermal water of West Coast Geothermal Province, Maharashtra, India (Chandrasekhar et al. 2018) 


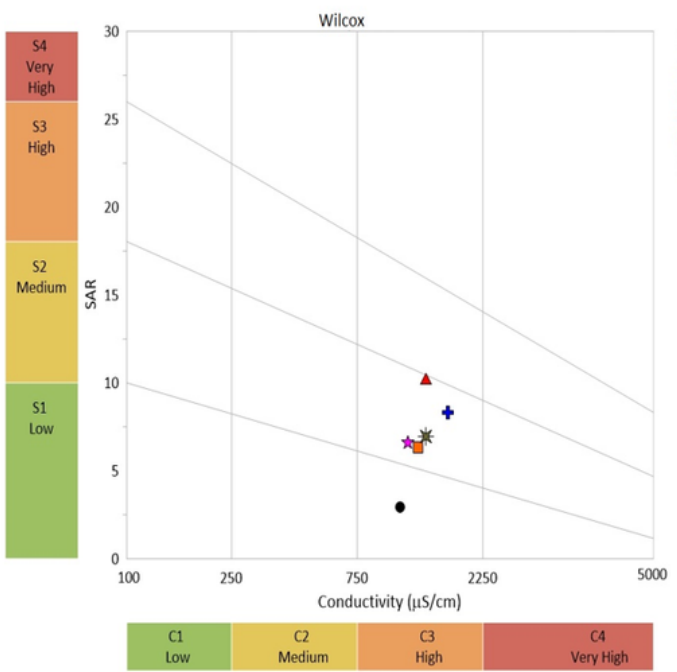

(a)

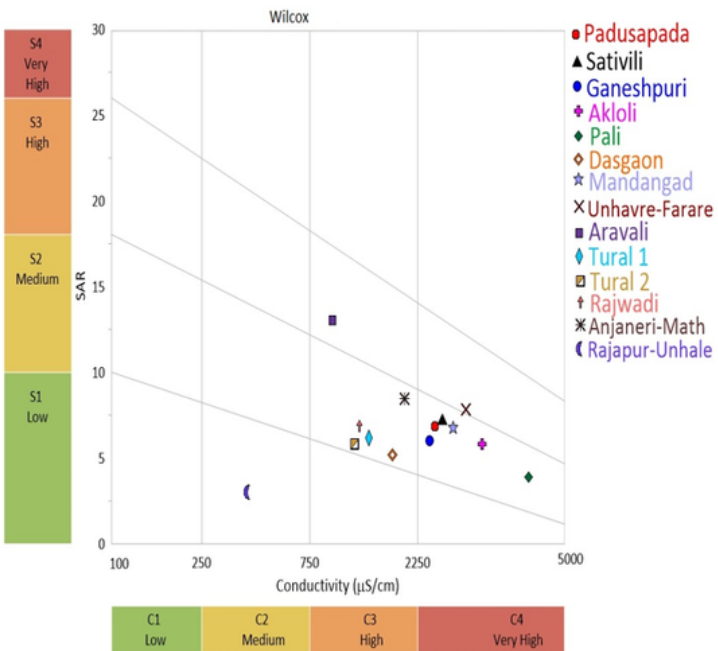

(b)
Wilcox

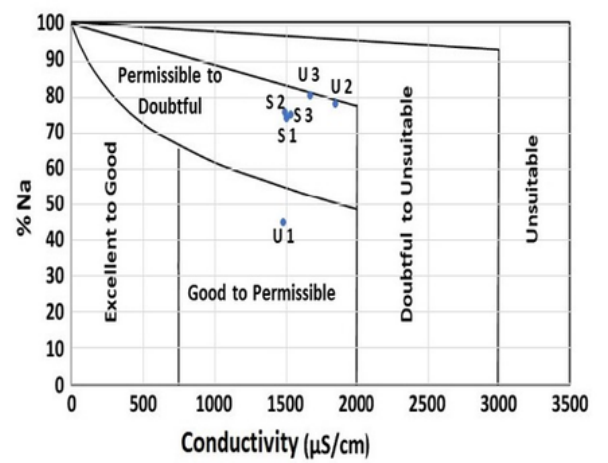

(c)

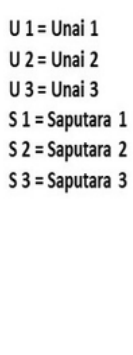

= Saputara 1

3 = Saputara 3

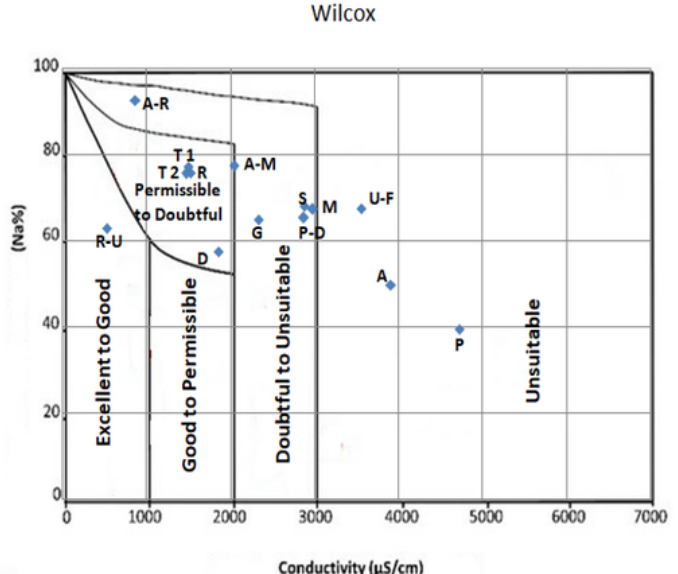

(d)

Figure 8

(a) Wilcox log plot for Southern part of Gujarat (b) Wilcox log plot for West Coast Geothermal Province (c) Wilcox Diagram for South part of Gujarat (d) Wilcox Diagram for West Coast Geothermal Province 
(a)

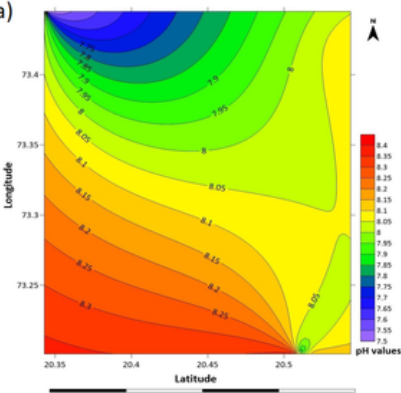

(e)

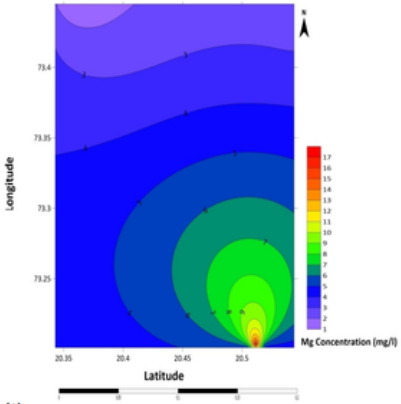

(i)

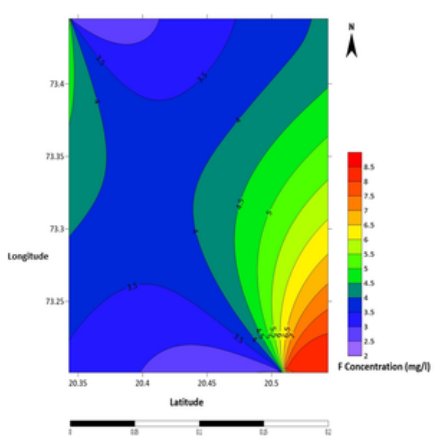

(b)

(f)

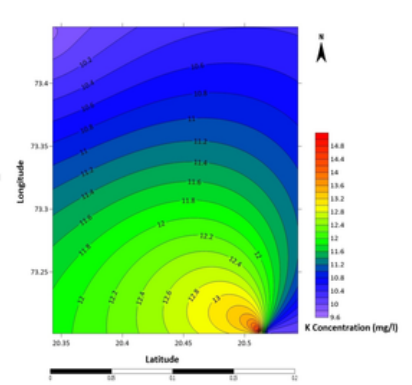

(j)

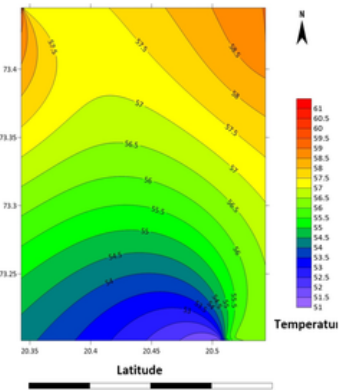

(c)

(g)

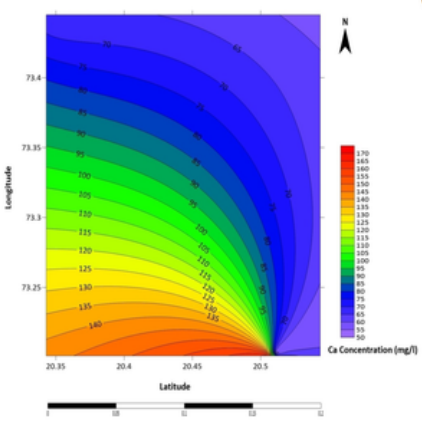

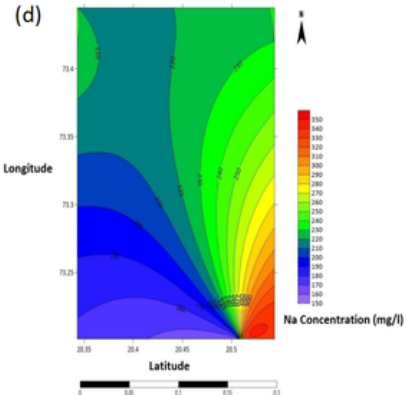

(h)

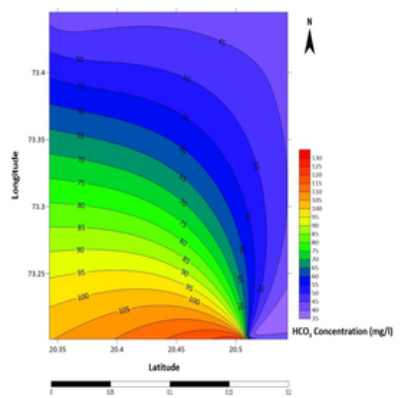

(k)
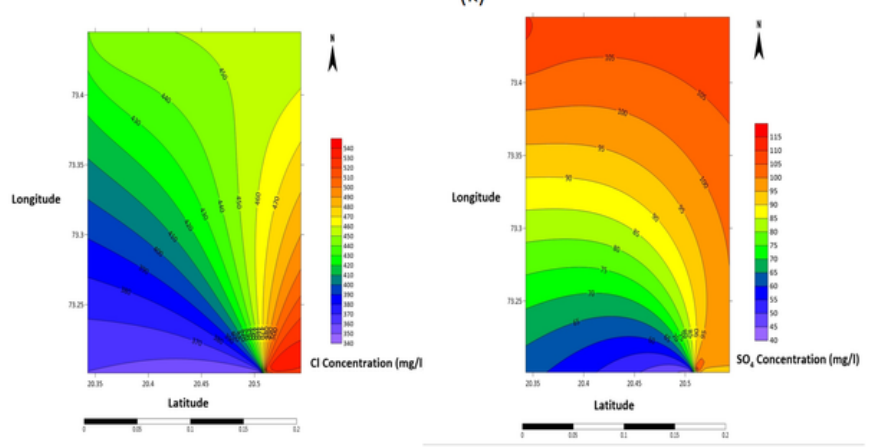

Figure 9

(a) Spatial distribution plot for geothermal spring water parameters Locations as per Table $1(\mathrm{pH})(\mathrm{b})$ Spatial distribution plot for geothermal spring water parameters Locations as per Table 1 (Temperature) (c) Spatial distribution plot for geothermal spring water parameters Locations as per Table 1 (TDS) (d) Spatial distribution plot for geothermal spring water parameters Locations as per Table 1 (Sodium (Na+) (e) Spatial distribution plot for geothermal spring water parameters Locations as per Table 1 (Magnesium (Mg2+) ion) (f) Spatial distribution plot for geothermal spring water parameters Locations as per Table 1 (Potassium (K+) ion) (g) Spatial distribution plot for geothermal spring water parameters Locations as per Table 1 (Calcium (Ca2+) ion) (h) Spatial distribution plot for geothermal spring water parameters Locations as per Table 1 (Bicarbonate (HCO3囚) ion) (i) Spatial distribution plot for geothermal spring water parameters Locations as per Table 1 (Fluoride (F-) ion) (j) Spatial distribution plot for geothermal spring water parameters Locations as per Table 1 (Chloride (Cl-) ion) (k) Spatial distribution plot for geothermal spring water parameters Locations as per Table 1 (Sulphate (SO42-) ion)
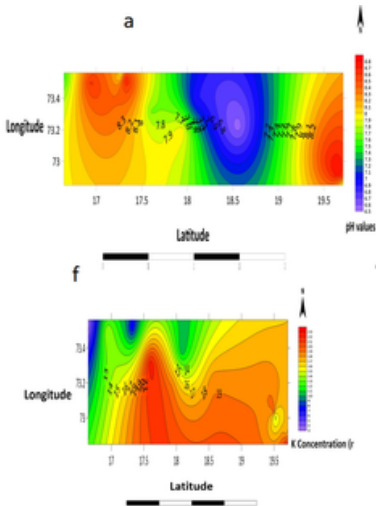

L Latitude
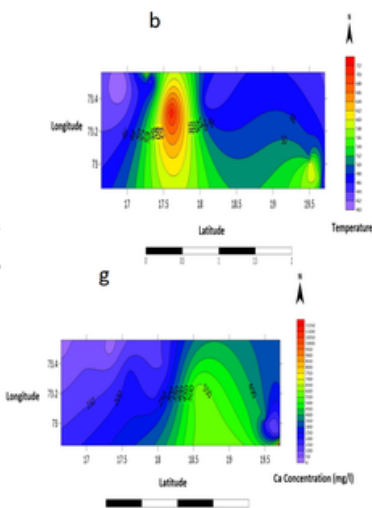
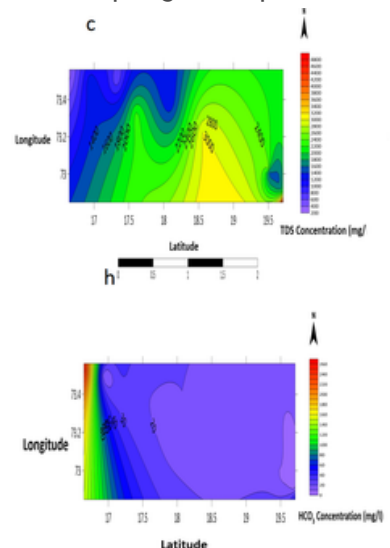

- Latitude
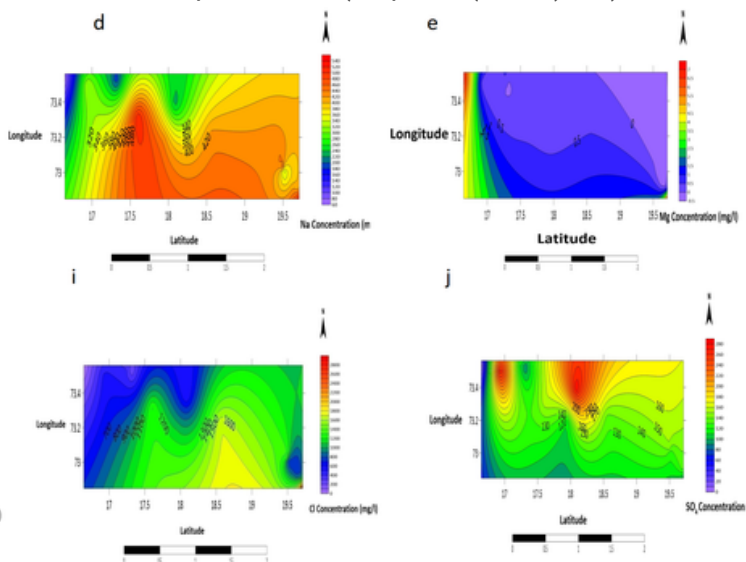
(a) Spatial distribution plot for geothermal spring water parameters Locations as per Table $2(\mathrm{pH})(\mathrm{b})$ Spatial distribution plot for geothermal spring water parameters Locations as per Table 2 (Temperature) (c) Spatial distribution plot for geothermal spring water parameters Locations as per Table 2 (TDS) (d) Spatial distribution plot for geothermal spring water parameters Locations as per Table 2 (Sodium (Na+) ion) (e) Spatial distribution plot for geothermal spring water parameters Locations as per Table 2 (Magnesium (Mg2+) ion) (f) Spatial distribution plot for geothermal spring water parameters Locations as per Table 2 (Potassium (K+) ion) (g) Spatial distribution plot for geothermal spring water parameters Locations as per Table 2 (Calcium (Ca2+) ion) (h) Spatial distribution plot for geothermal spring water parameters Locations as per Table 2 (Bicarbonate (HCO3囚) ion) (i) Spatial distribution plot for geothermal spring water parameters Locations as per Table 2 (Chloride (Cl-) ion) (j) Spatial distribution plot for geothermal spring water parameters Locations as per Table 2 (Sulphate (SO42-) ion) 